\title{
The Effect of Death on the Obligations Resulting From the Contract: A Legal Research in the Civil Law
}

\author{
Dr. Rabi Mahmoud Najeeb Alamuor \\ $\mathrm{PhD}$ in Civil Law
}

\begin{abstract}
This research examined the effect of death on the obligations resulting from the contract that was conducted prior to death, whether a written or unwritten one. In this regard, the researcher can understand the law's keenness that man should leave this life while his financial obligations are not bound to anybody and has no obligations, exactly as the law is concerned that man shall have his rights from the others and oblige them to implement their agreements. Accordingly, death, in its nature might come suddenly without prior notice and the dead man might have conducted one or more contract, and thus it is necessary to implement such obligation or discharge the quittance of the dead person from any debts or obligations. On the other hand, the importance of this paper comes to show how to deal with law in such incidents (the contract agreement). The researcher made the study and analyzed it while defining the contract agreement and its features and legal form, not to forget researching in the most important obligations incurred on the contracting parties and thus, showing the effect of death on the nature of the contract agreement whether the characters of the contracting parties is considered in the contract or not and then linking the effect of contractual obligations after the death of one party or both of them. The research was divided into an introduction and two themes; the first examined the definition of the contract agreement through two sections: first: defining the contract agreement, secondly: adopting the contract agreement. The second theme examined the effects resulting from the contract agreement; two sections were assigned to this theme; first: the obligations resulting from the contract agreement, secondly: the effect of death on the obligations resulting from the contract agreement. The conclusion included the most important results and recommendations.
\end{abstract}

Keywords: Death, Obligations, Law

DOI: $10.7176 / \mathrm{JLPG} / 94-02$

Publication date: February $29^{\text {th }} 2020$

\section{Theme one}

Essence of the contract agreement

The Jordanian legislator in the Civil law examined the rules of the contract agreement in the first chapter, section three that is assigned to employment contracts of the second book that organize the rules of the contracts.

In this context, the legislator assigned twenty four articles (articles: 780-804) and defined the contract agreement and its scope then indicated to the place and provisions of the contract. The researcher will - in this paper- define the contract agreement and its features then explain it clearly and easily.

\section{Part one}

Definitions of the contract agreement

Article 780 of the Jordanian Civil Law defined the contract as: "an agreement where a party undertakes to make or perform a work in return for compensation paid by the other party"1.

From this definition it becomes clear that the contract agreement has the following features:

1- It is a contract with the consent of the parties, and shall not be concluded in a specific form, but requires response and acceptance. It could be implemented in writing or orally. However, writing is not necessary except to prove the contract not conducting it. The party who will perform the work for the others' interest is called (the contractor) while the other party is called (the employer). There is nothing that prevents for making a formal contract agreement in case there is a specific text to write it. ${ }^{2}$

2- The contract is binding for both parties; the contractor is bound to complete the work and hand it then he shall insure thereof, while the employer is bound to receive the work after completion and to pay the compensation.

3- The contract agreement where each party takes a return for what he gave.

4- Consent occurs on two aspects, namely: the thing that should be made or the work to be implemented by the

\footnotetext{
${ }^{1}$ Dr. Jafar Al-Fadly, the summary in the civil contracts, Dar Al-Thaqafa for publishing and distribution, 1997, No. Ed. P 369. The resolutions of the Jordanian court of Cassation (rights) No. 4014/2013 (ordinary committee) dated 6/4/2014, Publications of Adala Center.

${ }^{2}$ Work contract, employment, labor rights: 1) To make use of article (2) of Labor Law and articles (780 and 805) of the Civil Code that the most aspect which distinguish employment contract is the aspect of supervision, management and fellowship in which work contract is independent. Since the concerned court was convinced of the evidence it heard that the aspect of supervision and fellowship exists then accommodating the facts of the lawsuit and applying the law on the clear facts is the job of the courts but not to the desire of the disputing parties. The court's conclusion regarding the verdict in labor rights (which it judged) is represented in paying a compensation for the forced termination and the end-of-service compensation and a compensation for the notice, un-work days, official holidays, Fridays and leave compensation is in agreement with the rules of the law.
} 
contractor (one of the parties) and the return in which the employer shall be the compensation (the other party). ${ }^{1}$

From this definition, it is noted that there is a similarity between the contract agreement and other contract. Consequently, it contained the rules of the contracts from different aspects. This was indicated in the clarifying memos in explaining the Jordanian Civil Law, which was derived from the Islamic jurisdiction, especially the contracts of manufacturing and the contracts with the mutual employee, with a balance between such rules in accordance with the developments of this age.

The contract has become at the present time an important contract due to the progress of civilization, development and as a reason for its entry into a new stage that is characterized by the state's interference in directing economic life. This led to the complexity of this contract so that the relationship between the contractor and the employer is not a relationship of a maker with a factory as was the case in the French law where the matter that the traditional rules mentioned in the contract for contracting are no longer compatible with the requirements of the evolving needs that led to the complexity of the aspects of this contract. Therefore, legislators in most countries of the world have developed separate provisions for this contract to be consistent with all of its cases and in varying forms ${ }^{2}$.

This wide concept of the contract agreement is consistent with the modern view and with what its legal organization reached in modern legislation. In fact, the contract agreement is a kind of contracts that includes submitting a specific service in return for a material thing, where the contact becomes similar to the sale one, or on non-ordinary order, as the contract agreement is similar to the agency contract. Consequently, all kinds of agreements for making/ repairing or transferring something (like building, repairing devices or machines) come under the title (contract agreement). Especially maintenance works, gained high importance nowadays due to the retreat of house service works; these last works are initiated now by professionals or specialized organizations that clean and press clothes, make repairs, painting and coloring, cooling heating and other services which man can not abandon nowadays.

On the other hand, there are various contract agreements that do not require a material return, but in return for a pure service or a non-material efforts; medicine and treatment, tuition lesson (special classes), travel agency services, legal/financial and accounting consultations or organizing parties and provision of services for the owner of party halls and celebrations .

On the other hand, some contract agreements have taken a special importance and caused the legislator to organize them under a specific name and make them subject to special rules with a purpose of complying with the general rules of the contract agreement in general ${ }^{3}$. In this context, the transportation contract in most countries has considered the legal organization and added special laws that organize transportation of all kinds (land, sea and air), not to forget using international rules that were organized by international, regional or dual agreements, especially for the transport of passengers or goods transportation ${ }^{4}$.

This issue was applied on other contracts such as hotel or publications that were produced and explained in many laws within the scope of the contract agreement in general so as to make such rules subject to these contracts.

\footnotetext{
${ }^{1}$ Malak Noor Khasawneh, contractual obligations resulting from financial compensations, MA thesis, UJ, 2004, p 266.

${ }^{2}$ Dr. Ja'far Al-Fadli, Al- Wajiz in the civil contract, Dar Al-Thaqafa Publishing and Distribution, 1997, No. Ed. P 369

2 Resolutions of the Jordanian Court of Cassation (rights) No. 186/2013 (five-member- committee) dated 19/2013. Adala Center Publications In case the court discovered that the relationship between two parties is a contractual one governed on transportation/ ID travel, but did not discuss the provisions of the contract as stated in the travel Id, and did not handle the rules and conditions of the civil responsibility and the evidence and did not discuss the law to be applied on the facts of this lawsuit, while did not consider the rules of article (79/2) of the Trade Law No. (12) of 1966 and article (122/a) of the civil aviation law No. (50) of 1985 which clearly indicate that Warsaw agreement (1929) and amendments especially article (17) which discuss the responsibility of the air carrier and safety of the passengers which state: (the carrier is responsible for damage that takes place in case of the death, injury of a passenger or for any other physical injury if the accidents causes the damage took place on the plane of during any ascending or descending operations as well as articles $(18,19,20,21$, and 22) and the subsequent divisions of the above said agreement, then it should consider thereof and show the applicability of these articles on the facts of the lawsuit based on the evidence submitted and the legal effect thereof.

3 Dr. Adnan Al-Sarhan, Ibd, p. 18.

${ }^{3}$ Resolutions of the Jordanian Court of Cassation (rights) No. 186/2013 (five-member- committee) dated 19/2013. Adala Center Publications. In case the court discovered that the relationship between two parties is a contractual one governed on transportation/ ID travel, but did not discuss the provisions of the contract as stated in the travel Id, and did not handle the rules and conditions of the civil responsibility and the evidence and did not discuss the law to be applied on the facts of this lawsuit, while did not consider the rules of article (79/2) of the Trade Law No. (12) of 1966 and article (122/a) of the civil aviation law No. (50) of 1985 which clearly indicate that Warsaw agreement (1929) and amendments especially article (17) which discuss the responsibility of the air carrier and safety of the passengers which state: (the carrier is responsible for damage that takes place in case of the death, injury of a passenger or for any other physical injury if the accidents causes the damage took place on the plane of during any ascending or descending operations as well as articles $(18,19,20,21$, and 22) and the subsequent divisions of the above said agreement, then it should consider thereof and show the applicability of these articles on the facts of the lawsuit based on the evidence submitted and the legal effect thereof.

2) It did not examine the rules of articles (70 and 73) of the law of Civil Aviation and to Warsaw agreement especially article (17) which discuss the responsibility of the carrier for the damage that may results from death or injury of the passenger or any physical injury that may occur to him if the accident that caused damage took place on the plane or during ascending or descending of the passengers as well as articles $(18,19,20,21$, and 22$)$ and the subsequent of the above said agreement, which shall take that into account and show the applicability of these articles on the facts of the lawsuit based on the evidence and the legal effect thereof.
} 
On the other hand, some contract agreements have taken a special importance and caused the legislator to organize them under a specific name and make them subject to special rules with a purpose of complying with the general rules of the contract agreement in general ${ }^{1}$. In this context, the transportation contract in most countries has considered the legal organization and added special laws that organize transportation of all kinds (land, sea and air), not to forget using international rules that were organized by international, regional or dual agreements, especially for the transport of passengers or goods transportation.

This issue was applied on other contracts such as hotel or publications that were produced and explained in many laws within the scope of the contract agreement in general so as to make such rules subject to these contracts.

This matter caused some writers to admit the existence of what they termed the special contracts, which are named ones but more specialized; for instance, the publication contract is first subject to the special rules of this contract then to the

contract agreement in general, which is a named contract, and finally to the general rules in the contract theory as a source of compliance.

If the view has become inconsistent with the current needs, due to the variation of contracting forms and its shapes in work, require flexibility in the legal organization of this contract to be consistent with the different case; the contract agreement - in most civic modern legislations- varied from the lease contract and employment contract, which is an ordinary issue. In this regard, the lease contract states on the benefit of something, while the contract agreement deals with work and if employment contract and the contract agreement state to work, then the first refers to the work itself whereas the second indicates to the its result. It is worth stating so that the judge can describe a contract as an agreement, then he should insure after interpretation that the main and real purpose of both contractors is that one of them independently and under his name to implement a specific work for the other contractor in return for compensation. These to features, knowledge in the future and implementing the work in return for a compensation, distinguish the contract agreement from other ones that are similar to it in specific cases such as sale, lease, work, agency, the contract of free professional, the public works, deposits and the company contracts.

\section{The second part}

\section{Aspects of the contract agreement}

The contract agreement is one of the agreed upon contracts for which no form is required and thus for conducting a contract, the necessary aspects should exist; the consent of both parties (the place and cause)

\section{Party one}

\section{Mutual consent}

Mutual consent in the contract agreement means the presence of the desires of the contractor and the employer. So that this consent be correct, the desire of both parties should be void of any defects, which means there are provisions, first: the provisions of the contract and the correctness of the contract. Moreover, to conduct the contract agreement acceptance and consent of both parties (the contractor and the employer) and they should agree on the details of the contract and the work that should be implement as well as the compensation that would be paid.

It is admissible to express consent whether clearly or implicitly since the contract agreement is one of the consent contracts ${ }^{2}$.

As we stated before, in order that the contract agreement is deemed legal, there should be a consent and acceptance on its aspects so that the employer and contractor will agree on the method of the contract and the work to be implemented by the contractor to the employer as well as the compensation which shall be paid in return ${ }^{3}$. These are the vital issues in the contract agreement on which consent and acceptance will be compatible without agreement thereon. Article (100/1) of the Jordanian Civil Law indicated to such issues as it states" (consent and acceptance are compatible if both parties agree on the vital issues for which they negotiated. As for agreement on some of these issues, it is not enough to bind both parties even if such agreement was confirmed in writing.

In addition, the truth of the contract agreement is another provision, which means the qualification of the contractors, without defects. As for the contractor, he should be an adult (completed eighteen years) sane, unreserved /wanted for ignorance or foolishness in terms of the fact that the contract agreement concentrates on

\footnotetext{
${ }^{1}$ See Al-Sanhouri, Al-Wasit, Vo. 7, Ed 1, p 31.

${ }^{2}$ Dr. Ja'far Al-Fadli, Ibd, p. 376

2 The resolution of the Jordanian Court of Cassation in its capacity in the lawsuit No. 222/2005 (a five-member committee) dated: $29 / 5 / 200$. Adala Publications' Center. 1) to make use of article 87-102 of the Civil Code that the contract is the consent of one of the contractors to accept the other and their agreement in providing the effect of the contract and the obligations of either party and acceptance of the vital issues in the contract. As for the details, the judge will decide them. 3) to make use of articles 99 and 100 of the Civil Code, as the law did not required agreement on all vital issues and details but the agreement on all vital issues.

3 Dr. Mohammed Labib Shanab, explaining the Civil Code, part 4, p. 55.
} 
interest and damage ${ }^{1}$.

As for the employer, this is considered among the acting works, since among his obligations in the contract to pay the compensation for the contractor and thus concluding this contract is an act that requires qualification to take an action therein. If he was reserved/ wanted for ignorance or foolishness or a minor who can not distinguish things, then his contract relies on the consent of his custodian or guardian. However, the contract agreement is deemed for the employer as a neglect by the management, such as the contract which the employer convenes with a contractor to repair his house or to sew a suit, then such contracts are one of the administration tasks, where it is enough that the employer shall be qualified and thus the minor may conclude the contract agreement in his capacity as the work owner without a need to have the consent of his custodian or guardian. The defects of consent in the contract agreement are the same as in other kinds of contracts, and we would just refer to them. However, consent defects in the Jordanian Civil Law are three: forcibly, by mistake and deception with extreme wrong.

\section{Second Branch \\ The form \\ First section \\ (Work in the contract agreement)}

In contract agreements, the place has to faces; as for the obligations of the contractor he should implement the work assigned to him, whereas for the obligations of the employer, to pay the compensation he undertook to pay for the contractor. Work in the contract is one of the faces of the form which the contractor undertakes to do; the contractor either performs a work or makes something if he provides the work and materials, then this is called (Istisna'/ manufacturing) as per the Islamic jurisdiction. However, if the contractor's role is limited to provide the work whereas the employer provides the material, then the contractor is considered as a joint employee, and the work of the contract shall comply in applying the general rules in the provisions of the form/ place, namely to be possible, specific, can be appointed and to be legal.

We have indicated that the form/place of the contract agreement is double; its first place is the work where the contractor undertakes to provide to the employer in return for the compensation paid by the latter. We have known in the definition of the contract agreement that the contractor either makes something or performs a work ${ }^{2}$.

The work subject of the contract shall be a mental one whether legal (e.g. contracting with an attorney to raise a lawsuit before one of the courts, or literally, artistic such as contracting with a writer to write an essay, an artists to draw a picture of an oil paint, a doctor to make a plastic surgery, an engineer to put designs for a house or a memorial. The contract may require a material work as they might be good to be a place or a subject for the contract which can not be limited. Despite variation and different kinds, they all can be a title of the contract. In this essence, the French courts considered the contract convened the a wife of war prisoner in Germany with a person to smuggle her husband from jail is considered a contract ${ }^{3}$.

Work might be related a specific thing which does not exist, but the contract intends to find it by a material he provides or provided by the employer. It might be related to something that really exists which is owned by the employer's work depends on that thing and work may not relate to a specific thing but it is merely a work such as transportation, publication and advertisement. Work varies in terms of time from one agreement to the other.

\section{Second theme \\ The Compensation (return) for the contract}

The Jordanian Civil Law calls it (the return), since it may include something in return for the work and the material used therein, which the contractor provided for the contract agreement in case of (manufacturing/Istisna'). The return therefore is more comprehensive than the term of wage. The Jordanian Civil Law best chose this case. The wage or return is an aspect in the contract agreement and one of the aspects of the contract in addition to the work. The Jordanian Civil Law did like, did not decide the return in the contract agreement like other laws, but by applying the general rules of the work in the contract theory, the return might be an amount of money (in most cases), but it can be in kind or in return for a benefit of any other financial right not to forget that it can be a work or refraining from doing a work (article 158 of The Jordanian Civil Law)

1) For the financial actions, it is required that the return shall be in money.

2) It could be in-kind or in return for any benefit/ interest or another financial right not to forget that it can be a work or refraining from doing a work ${ }^{4}$.

1 Dr. Adnan Al-Sarhan, Ibd, p. 33,

2 Dr. Ja'far Al-Fadli, Ibd, p. 378

${ }^{2}$ Dr. Adnan Al-Sarhan, Ibd, p. 38

${ }^{3}$ Nancy, 25 arvill 1947, gaz.pal. 1947, 1, p. 142

${ }^{4}$ The resolution of the Jordanian Court of Cassation in its capacity in the lawsuit No. 4192/2005 (a five-member committee) dated: 4/6/2006. Adala Center Publications. 1) It is well -known in the jurisdiction of the court of cassation that the legal adaptation for the facts of the lawsuit is not subject to the desire of the opponents nor does it prevent the court from giving it the correct legal adaptation since the court of the subject is the competent body in interpreting the contracts guided by the conditions of the lawsuit and what the parties of the contract meant in 
As an example for the contract agreement if a surgeon undertook to make a surgery for the contractor and in return the latter undertakes to build a house for the first. On the other hand, the contractor may do a work the employer gives his car or transfers the ownership of his house or by giving him a specific amount of olives or dates.

In return or wage in the contract (the place of compliance by the employer) there should be conditions that exist in the obligation place. These conditions are: the return shall be available, specific or can be specified and legal or can be dealt with.

\section{Second theme}

The implications of the contracting contract

Second theme

The implications of the contracting contract

The contract agreement is one of the contracts that are binding to both sides, so it arranges obligations for the contractor and for the employer. Therefore, we must search in these obligations and explain the effect of death on them, and the contractor may contract with a sub-contractor (the second contractor) to complete some of the works assigned to him or to complete all these works. Therefore, we have to discuss this matter within two themes. The first theme is the obligations arising from the contract of contract, while the second is the effect of death on the obligations arising from the contract of contract.

\section{The first section:}

The Obligations Arising from the Contracting Agreement

The first part: The Obligations Arising from the Contract Agreement

Articles (783-791) of the Jordanian Civil Code stipulated for the obligations of the contractor, and the first of these obligations is the commitment to complete the work as agreed upon. For the first time, the content of this commitment appears to be easy. The contractor is obligated to carry out the work as agreed upon. The doctor must treat his patient and the carrier takes/carries the traveler or merchandise to the intended destination and the repairer repairs the car or a device that he is entrusted to him, and so on. However, studying the contractor's commitment to complete the work entrusted to him requires studying a number of points. We can say that it is a set of subobligations that flow into the course of this main commitment to carry out the work as agreed. Article 785 of the Jordanian Civil Code states that: (the contractor must complete the work in accordance with the terms of the contract, if it is found that he is performing what he undertook in a defective or contradictory manner, then employer may request the termination of the contract at once if repairing the work is not possible, or if the repair is possible, then the employer may request the contractor to abide with the terms of the contract and correct the work within a reasonable period. If the time limit expires without correction, it is permissible that the employer may ask the court to terminate the contract or release him to entrust another contractor to complete the work at the expense of the first contractor. ${ }^{1}$

As a result, the contractor is bound to implement the work in the way as agreed in the contract agreement and as peer the provisions mentioned in it. However, the disagreement on a specific way to achieve the work does not mean that the contractor may complete it as he wishes, but shall follow the standards of the profession especially the origins and principles of the career and art in the work he implements where every work has traditions and principles and if he violates them, then he shall be responsible for that violation.

If it was agreed that the employer will provide the materials of the work and the contractor shall only do the work, then this does not mean that tools and machines shall be provided by the employer; the Jordanian Civil Code requires clearly that the contractor shall- in addition to his work- provide the additional needed machines and tools on his expense, but here there are some exceptions.

Among the obligations of the contractor is to provide necessary care while implementing the work, upon adapting the contract as a contract agreement where it is not enough to decide the procedure of responsibility in this contract not the degree of care which a contractor shall exert while implementing the required work. At this

accordance with the rules of article 239 of the Civil Law. 2) Article 157 of the Civil Law required that each contract shall have a place to be added thereof. Article 158 of the same law admitted that the form of the contract shall be a work and if the contract was impossible in itself, then the contract shall be deemed as void. In addition, article 163 of this law requires that the place shall be subject to the rules of the contract, as prohibiting dealing in something makes the contract void. Since the place of the contract is the work in a restaurant in Al-Bayadir district, and since investigation took place about whether the leased real estate by the defendant can be licensed by the official bodies to be operated as a restaurant according to the purpose stipulated in the work agreement between the lawsuit parties, is an important issue to decide the lawsuit since of the legislator is prohibited from dealing with something, then the contract shall be deemed as void. 3) This does not include the compensation for arbitrary dismissal stipulated in the Labor Law for the worker who is bond with a specified period work contract.

${ }^{1}$ Resolution of the Court of Cassation in its legal capacity No. 525/1999 (a five - committee) dated 8/9/1999. Adala Center Publications. 1) if the defendant did not present evidence to prove the conditions agreed upon which were implemented during the contract, in a defective way, and did not prove his right, then $20 \%$ of the contract value will be deducted (the completed works). In addition, it he did not prove allowing such deduction before the court of cassation, then the court shall refer to article 785 / civil which decide the legal ways which the employer shall seek to use. 
point, the contractor is bound in the contract agreement to comply and exert care or what is called commitment to achieve a purpose or obligation as per the obligation imposed on the contractor.

Among the other obligations on the contractor is his responsibility for his acts where the Jordanian legislator considered a general and comprehensive text stating that the contractor shall guarantee the results of his act and profession in terms of damage or loss whether by default or neglect as the guarantee is void if that caused an incident that is unavoidable. ${ }^{1}$

Furthermore, the contractor is bound to complete the work within the period as agreed on. However, it there is not agreement on a specific period, then it is necessary to complete the work within a reasonable period which allow thereof due to the nature and amount accuracy and as per the standards of the profession and what the employer knows. ${ }^{2}$

In case the contractor violates his obligations to complete the work, then he shall be responsible for such violation, and thus the employer/ work owner may demand for his rights in terms of compensation in both cases where he may demand to terminate the contract. In this regard, if the contract contained a penal provision that require imposing penalties for each day or week or any period of delay from completing the work on the due time, then such penalty shall be applied as long as it equals the damage inflected on the employer due to the delay.

The contractor also complies to deliver the work to the owner after completion as the delivery varies according to the nature of that thing/ work, with the need to decide the place and time of handover and the contractor bears the responsibility for the damage of the thing prior to the handover and complies with the guarantee.

As for the obligations of the employer, he shall exert his best efforts to enable the contractor begin the work, while if the contractor needs a building license, then the employer shall provide it before starting work. It is used that the employer does not agree with the contractor unless after obtaining the building license. However, they may agree prior to having the building license and in this case, the employer shall have it before the date of starting the construction. In addition, if the employer undertook to provide the materials that will be used in the work, then he shall comply with that prior to starting work implementation to enable the contractor implement the work. ${ }^{3}$

Moreover, the employer shall allow the contractor complete the work without putting obstacles and shall not withdraw work after assigning it except for a legal reason; he can not change his mind by his desire alone and to terminate it except within the limits and provisions stipulated by law.

Furthermore, the law requires the contractor to handover the work after completion since handover and receiving are a complete processes.

The employer receives the thing after the contractor has completed it, and the work becomes under his custody without any obstacles that prevent him from owning it. The handover of the thing/project takes place according to its nature; if the thing was movable, then handover takes place by ownership through hand over, while if it is a

\footnotetext{
${ }^{1}$ Resolution of the Court of Cassation in its legal capacity No. 3898/2003 (a five - committee) dated 16/4/2004. Adala Center Publications. The uses of articles 786, 788 and 789 of the Civil Code which deal with the responsibility of the contractor and engineer who designed the building and supervised implementation and the engineer whose role was limited in designing the building, that the compliance in the compensation for the defect of damage stay existing against the contractor and engineer even if the defect was due to a default in the land and the owner accepted to build the building on the defected land require compensation as estimated by the experts in accordance with article 788/2 of the Civil Code. * The decision of the Court of Cassation stated that the interest results from compensation and guarantees as ruled by the court for one of the parties as of the date of the final decision to make the verdict in force if such rights were established and became due prior to amending article $167 / 3$ of the law of Civil Trial Code.

* Article 267 of the Civil Code clarifies the conditions with which the injured person is entitled to compensation for moral damage exclusively, which is the infringement of others in his freedom, in his display, in his honor, in his reputation, in the social status, or in his financial consideration, and that the person's home is cracked if It constitutes material damage with which compensation is due, in accordance with the provisions of the contract of contract mentioned in the Civil Law. No moral damage is caused in the meaning of the aforementioned article. * The provisions of Articles 786, 788, 789, and 791 of the Civil Code are used, because the contractor and the engineer's responsibility to guarantee the damages in the building extends for ten years from the date of handing over the building to its owner, and that the warranty claim is not heard after one year has passed since the destruction occurred or the defect is discovered .

* If the construction was started around the middle of 1996, and the building was handed over to its owner, then during the year 1997, the defect was discovered by the appearance of cracks, which took place at the end of November of 1997, and the defendants were notified according to the legal warning. The distinguished tiger gave a judicial answer in which he mentioned in the fourth item what The following (I reviewed you after receiving the warning to contribute to the repair of what is possible after consulting the designer, but you refused this on the pretext of reviewing the Royal Scientific Society) On the date of 9/14/1998, the person against him instituted the security claim against him, so the payment over time is required to respond:

1 - To file a lawsuit during the year.

2- For the issuance of an acknowledgment of responsibility for the privileged one, the statute of limitations shall be terminated, on the grounds that the legal notice and answer are judicial measures.

* According to Articles 786 and 788/2 of the Civil Code, the contractor is the guarantor of the damage or loss generated by his act and manufacture, whether by infringement or negligence or not, and the guarantee will not be excluded from him unless the damage resulted from an accident that cannot be prevented.

* The second paragraph of Article 788 of the law requires the guarantee, even if the defect or subsequent demolition of the building is caused by a defect on the land itself or the employer is satisfied with the construction of the defective facilities.

* The interest arises from the compensation and the implications that the court rules for one of the litigants, as he claimed them, as is the case in the case presented, as required by Article 167/3 of the Code of Civil Procedures.

${ }^{2}$ Dr. Ja'far Al-Fadli, Ibd, p. 391

${ }^{3}$ Dr. Mohammed Labib Shanab, Ibd, p. 149
} 
real estate, then the handover takes place after the contractor abandons it and the employer dominates on it.

In this essence, the Jordanian Civil Code did not show the time of handover of the work but left it to the general rules. In referring to the rules relating to implementing the obligation, we found that article 334/1 of the Civil Code state that: 1) It is necessary to promptly pay the dues after arranging the final obligation unless there is an agreement or a text that require otherwise). In most case, the contracting parties agree on a specific time to complete the work, and by such time the contractor should have completed the work, and at this moment, he shall hand it over to the employer (the work) unless if they agreed on a different time for handover. ${ }^{1}$

Similar to the time of deliver, the Jordanian legislator did not specify the place of work handover, but by referring the general rules in implementing the obligations, if the contractor's work concentrated on the real estate, then work handover shall be in place where that real estate is located, and the same applies in case of the movables as they should be handed over in the place where they were at the time of obligation establishment (article 336). On the other hand, if the subject of obligation was a specific thins, then the work should be delivered in the place where it was at the beginning of the obligation unless otherwise. 2) In case of other obligations, compliance with the place shall be the address of the debtor on the time of completion or in the place of the debtors business if obligations was related to such works). The employer is bound to pay the compensation since it is an aspect of the contract agreement otherwise the contract will be untitled and is not a contract agreement.

The employer complies to pay the compensation to the contractor either by himself or another person (a guardian, custodian or an attorney). This compensation discharges the employer. However, if the employer dies, then it will not affect the contract agreement and we will discuss that in the second theme, which is the basis of our research.

\section{The second theme}

The effect of death on the obligations resulting from the contract agreement

The employer or perhaps the contractor may die, prior, during or after starting the work. Here is an explanation of the effect of the death of either party resulting from this contract.

First: the effect of the death of employer in the obligations resulting upon him due to the contract agreement: The Jordanian Civil Code did not discuss this issue within the context of the contract agreement, and the same applies on the Egyptian Civil Code, but used the general rules which state that the origin of the financial contracts is that they are not affected with the death of either party after concluding the contract, which comes due to the fact of not considering the character of the contractors therein after the contract is correct. Afterwards, the resulting obligations are transferred to the inheritors of the diseased who implement them within the limits of the inheritance of the dead person.

Based on this rule, if the employer dies, his resulting obligations (based on the contract agreement) are transferred to his inheritors, regardless whether they provide them with the same benefits expected to the dead person, and regardless of the consent of the inheritors to receive the works of the contract whose ownership refer to them or not. As a result, they comply to enable the contractor perform his work and shall refrain from causing any obstacles that may hinder the implementation of the work. Also, they shall comply to hand over the work once achieved/ completed and pay the compensation, as if their dead person is alive. ${ }^{2}$

In addition to that, they may not terminate the contact with the consent of the contractor or by a court verdict, or based on the law according to the general rules of the Jordanian Civil Code, contrary to some laws in some Arab states which give the employer and his inheritors the right to terminate the contract by their desire or by sole desire of the inheritors. As for the effect of the death of the contactor in the resulting obligations due to the contract agreement, we should differentiate the death of the contractor between two cases: first: the qualifications of the contractor are considered in the contract agreement, second: such qualifications shall not be considered. ${ }^{3}$

In the first case, if the contractor dies, the contract shall be automatically terminated without a need for a lawsuit to demand for terminating the contract by either party, since it is not possible to follow up the work due to the death of the contractor and if the employer desires to continue with the implementation through the inheritors of the contractor, then he needs to conclude a new contract agreement with them. In the second case, the general rules which stipulate the non-termination of the contract after the death of either party; if the contractor dies, in this case, the contract will not be terminated, but his obligations will be transferred to his inheritors, where they shall replace him in fulfilling his obligations within the limits of his inheritance and complete the work. In addition, they shall insure the damages resulting from total or partial implementation, where the contractor's obligations based on this guarantee is transferred to his inheritors after his death, which is similar to the transfer of defect and

\footnotetext{
${ }^{1}$ In the large contracts to establish factories, there is something called hand-key - delivery where the contractor undertakes to deliver the whole factor after completion.

${ }^{2}$ Al-Sanhouri, Al-Wasit, Vol. 7. p. 256

${ }^{3}$ Dr. Ja'far Al-Fadli, Ibd, p. 444

3 Malak Noor Khasawneh, effect of death, Ibd, p. 271
} 
default to the inheritors, even if the period of guarantee was long, as the case in the building contract for instance, where the guarantee period my extend to ten years, as per the period agreed upon between the contractor, or for the period as stipulated in the law. ${ }^{1}$

If this guarantee was insured through financial bonds, then the contractor died during the guarantee period, the guaranteed money shall be kept with the employer until the elapse of the period agreed by the guarantee. However, in case of damages resulting from the works of the contract, the employer may spend from the reserved money to cover the costs of maintenance and other costs. In case the period of the guarantee elapsed without any damage, the employer shall comply to return the money of the guarantee to the inheritors of the contractor. ${ }^{2}$

In case there are no enough guarantees possessed by the inheritors to the good implementation, then the employer may raise a lawsuit to the court demanding to terminate the contract agreement, where the contract may not be automatically terminated with the death of the contractor (in such case), and the judge shall view the topic of the lawsuit, then decide whether to issue a verdict to terminate the contract or to reject the lawsuit and continue implementing the contract agreement.

In case the employer is the one who provided the material (sewing cloth to make dresses) then the sewer made it and died before sewing it, in this case the employer shall retrieve - from the inheritors of the sewer- the sewed cloth and pay them the cost of sewing. However, if the contractor is the one who provided the material (such as making furniture) and the contractor bought wood, paid fees and costs and completed some of them, then the employer shall be the inheritors the costs of the wood, fees and costs if the employer used the commodity. However, if the work was useless, then it will not be approved. Work is considered useless if the employer - after the death of the contractor- could not find another contractor to complete the work, and here, he is forced to leave it.

Whether the contract ended by itself with the death of the contractor and his personal qualifications were considered or if the court decided to terminate the contract due to the death of the contractor, then the employer shall pay the inheritors whether the value of the works which were achieved by the contractor or a value that is equal to the benefit gained by the employer due to the works of the contractor and the compensation is restricted on the least two values. ${ }^{3}$

\section{Conclusion and recommendations}

At the end, the researcher would present the most important results and recommendations reached through this research.

1- The contracts that are terminated with the death of the one or both contracts are the ones that apply on work where the character of the contractor is considered or provided in the contract.

2- The resulting obligations are transferred to the employer based on the contract agreement to his inheritors. However, if the contractor dies, then the court would check if his natural character is considered or mandated in the contract.

3- In case the obligations incurred on the contract are transferred to his inheritors, then the employer shall submit a lawsuit demanding to prevent the inheritors from completing the contract if they do not posses enough guarantees.

4- In case the contract is terminated due to the death of the contractor, then the Jordanian Civil Law obliges the employer to pay the actual value of the work that is completed by the contractor before his death.

5- The Jordanian Civil Law did not oblige the inheritors of the contractor to handover the materials that he provided and used them for work in case the contract is terminated.

\section{List of resources and references}

1- Dr. Ja'afar Al-Fadhli, Al-Wajeez in Civil Contracts, 1997, Dar Al-Thaqafa Library for Publishing.

2- Dr. Adnan Ibrahim Al-Sarhan, Explaining the Civil Law, Named Contracts, 2013, Dar Al-Thaqafa Publishing.

3- Malak Nour El-Din Khasawneh, Contractual Obligations Resulting from Financial Compensations, Master Thesis, University of Jordan, 2004

4- Dr. Muhammad Labib Shanab, Explaining the Civil Law, Part Four

5- Abdul Razeq Al-Sanhouri, the Mediator in Explaining the Civil Law

6- Jordanian Civil Law of 1976

\footnotetext{
${ }^{1}$ Dr. Ja'far Al-Fadli, Ibd, p. 444

${ }^{2}$ Malak Noor Khasawneh, effect of death, Ibd, p. 273

${ }^{3}$ Dr. Ja'far Al-Fadli, Ibd, p. 445
} 